\title{
Lignification and cell wall thickening of ray parenchyma cells in Scots pine sapwood
}

\author{
Katrin Zimmer,** and Andreas Treu ${ }^{* * *}$ \\ Norwegian Institute of Bioeconomy Research, Pb.115. 1430 Ås., Norway \\ *Corresponding author; email: katrin.zimmer@nibio.no \\ **ORCID: https://orcid.org/oooo-ooo3-3687-9697 \\ ***ORCID: https://orcid.org/oooo-ooo2-1550-2375 \\ Accepted for publication: 27 April 2021
}

\begin{abstract}
Scots pine exhibits variations in ray anatomy, which are poorly understood. Some ray parenchyma cells develop thick and lignified cell walls before heartwood formation. We hypothesized that some stands and trees show high numbers of lignified and thick-walled parenchyma cells early in the sapwood. Therefore, a microscopic analysis of Scots pine sapwood from four different stands in Northern Europe was performed on Safranin - Astra blue-stained tangential micro sections from outer and inner sapwood areas. Significant differences in lignification and cell wall thickening of ray parenchyma cells were observed in the outer sapwood between all of the stands for the trees analyzed. On a single tree level, the relative lignification and cell wall thickening of ray parenchyma cells ranged from $4.3 \%$ to $74.3 \%$ in the outer sapwood. In the inner sapwood, lignification and cell wall thickening of ray parenchyma cells were more frequent. In some trees, however, the difference in lignification and cell wall thickening between inner and outer sapwood was small since early lignification, and cell wall thickening was already more common in the outer sapwood. Ray composition and number of rays per area were not significantly different within the studied material. However, only one Scottish tree had a significantly higher number of ray parenchyma cells per ray. The differences discovered in lignification and cell wall thickening in ray parenchyma cells early in the sapwood of Scots pine are relevant for wood utilization in general and impregnation treatments with protection agents in particular.
\end{abstract}

Keywords: Cell wall thickening; lignification; Pinus sylvestris L.; wood anatomy; ray parenchyma; treatability.

\section{INTRODUCTION}

Scots pine (Pinus sylvestris L.) exhibits variations in its rays' anatomical structure, and these variations are only poorly understood. Scots pine has a broad natural geographic distribution, covering boreal Eurasia and spreading southwards to Spain and Turkey (Mátyás et al. 2004). Consequently, the species needs to adapt to significant variations in environments and growing conditions, which causes hydraulic and anatomical adjustments (Antonova \& Stasova 1993; Berninger 1997; Poyatos et al. 2007; Yaman 2007; Martínez-Vilalta et al. 2009; Lande et al. 2010; Martin et al. 2010; Zimmer et al. 2014a, b). Differences in stand-dependent anatomical features of Scots pine have earlier been reported, which influence the processability of wood, for example, their treatability (Zimmer et al. 2014a).

One of these anatomical features of Scots pine, the uniseriate rays (Richter et al. 2004), consists of ray parenchyma and ray tracheids (Wagenführ 2007). Both cell types differ in structure and function: ray tracheids redistribute water in the radial direction, whereas parenchyma cells serve to store and mobilize metabolites and form heartwood substances in the transition zone. The death of ray parenchyma cells occurs later than that of ray tracheids, which lose their organelles directly after their differentiation (McCann 1997; Spicer \& Holbrook 2007). Ray parenchyma cells remain alive for several years, and the functionality of the cells can remain throughout the sapwood. (Spicer \& Holbrook 2007; Tulik et al. 2019).

Several studies (Balatinecz \& Kennedy 1967; Mann 1974; Nakaba et al. 2008; Zheng et al. 2014) described early and successive lignification of ray parenchyma cells in the sapwood of Pinus banksiana, Pinus densiflora, and hard pines of the Pinaster Lariciones type (such as Pinus sylvestris). Nakaba et al. (2008) reported lignification and cell wall thickening in ray parenchyma cells of Pinus densiflora and Pinus nigra before heartwood formation, and this development started in ray 
parenchyma cells adjacent to ray tracheids. The appearance of thickened cell walls in ray parenchyma cells in Scots pine sapwood was reported earlier by Bauch et al. (1983) and Nyrén and Back (1959). In the sapwood of Radiata pine (Pinus radiata), only $7 \%$ of parenchyma cells lignify before heartwood formation (Bamber et al. 1983).

Unlignified ray parenchyma cells collapse under pressure, steaming, or rapid drying of the wood. This collapse produces interstitial spaces that provide relatively free entry of liquids into the sapwood when the wood is impregnated (Bamber 1973). A high degree of lignification and cell wall thickening of ray parenchyma cells in Scots pine sapwood could withstand these forces resulting in lower treatability.

This study's main objective was to analyze anatomical differences in ray parenchyma cells in the outer and inner sapwood of Scots pine from four different northern European stands. We wanted to analyze (1) the differences in ray composition and ray frequency and (2) test the hypothesis that some trees in some stands have high numbers of lignified and thick-walled parenchyma cells already early in the sapwood.

\section{MATERIALS AND METHODS}

Microscopic analysis was performed on tangential longitudinal sections of Scots pine (Pinus sylvestris L.) sapwood at two radial positions: in the outer sapwood close to the bark (OSap) and the inner sapwood close to the heartwood (ISap). Sections were prepared from the northern side of stem discs (taken at a tree height of $1.30 \mathrm{~m}$ ) of 12 trees, where three trees were selected from the middle diameter class of four different stands, three from Norway $\left(\mathrm{N}_{1}, \mathrm{~N}_{4}, \mathrm{~N} 8\right)$ and one from Scotland (Sc2). The four stands had very different climates and growth conditions (Table 1) and material properties, as described in Zimmer et al. (2014b).

Small wood blocks were softened in purified water (by filtration) for $24 \mathrm{~h}$ before sectioning. Tangential longitudinal sections were prepared at a thickness of ${ }_{12-16} \mu \mathrm{m}$ using a Reichert sliding microtome. For the outer sapwood, sections were prepared from annual rings two and three from the cambium. For the inner sapwood, sections were taken two annual rings before the transition zone, with a varying sapwood age of 34 to 69 years. The sections were stained for 2 min each in $1 \%$ Safranine and $1 \%$ Astra blue (similar to Srebotnik \& Messner, 1994) and rinsed until the rinsing water contained no visible stain. The sections were dehydrated with an ethanol series ( $5 \mathrm{O}, 75$ and $96 \% \mathrm{EtOH}, 3 \mathrm{o} \mathrm{seach}$ ), dried on a heating plate at $40^{\circ} \mathrm{C}$, and mounted in Pertex (HistoLab, Västra Frölunda, Sweden). The age of the annual ring was noted for the respective samples (Table 2, for inner sapwood).

Microscopic images were recorded using a Leica DMR light microscope with a Leica DFC 425 camera. On three tangential longitudinal areas of $1.5 \mathrm{~mm}^{2}(\times 5$ magnification), the total number of rays was counted for each radial position, and the number of rays per $\mathrm{mm}^{2}$ was calculated. Images ( $\times 20$ magnification) of the tangential longitudinal surfaces were used to analyze the structure and composition of ray parenchyma and ray tracheids of at least 39 rays per position.

Ray tracheids are usually found at the margins of rays, edging ray parenchyma cells on the top and bottom of the rays (Figs 1 and 2). However, ray tracheids often also occur in the center of rays, either as single-cell rows or in rows of several cells between ray parenchyma cell rows. The distinction between those two cell types was unproblematic due to the pit structure of the individual cells. Diagnostic features were the cross-field pits between ray parenchyma and axial tracheids, if present bordered pits between ray tracheids and axial tracheids, and bordered pits between radially adjacent ray tracheids.

The Safranine - Astra blue contrast staining was used to determine the presence of cell wall thickening and lignification in the cell walls of all ray parenchyma cells (hereafter lignified, lignification throughout results) previously studied for ray composition in the inner and outer sapwood (Zimmer et al. 2014a). In this study, a total of 1304 rays were analyzed.

For statistical data analysis, the JMP version 10.0 software (2012) from SAS Institute Inc. (Cary, North Carolina) was used. Anatomical differences between stands, trees, and radial position were determined with ANOVA and Tukey Kramer HSD

Table 1.

Stand description, growing conditions, and average material properties.

\begin{tabular}{|c|c|c|c|c|c|c|c|c|c|}
\hline Stand & Lat & Long & Alt & AMT & AMP & RPD & Age & $\mathrm{TH}$ & Diam. \\
\hline $\mathrm{N} 1$ & $66^{\circ} 53^{\prime} \mathrm{N}$ & $15^{\circ} 17^{\prime} \mathrm{E}$ & 70 & 2.66 & 646 & 11.24 & 161 & $19 \cdot 42$ & 27.96 \\
\hline $\mathrm{N}_{4}$ & $61^{\circ} 40^{\prime} \mathrm{N}$ & $11^{\circ} 17^{\prime} \mathrm{E}$ & 431 & 2.11 & 590 & $5 \cdot 36$ & 149 & 16.82 & $22.5^{8}$ \\
\hline N8 & $60^{\circ} 25^{\prime} \mathrm{N}$ & $05^{\circ} 19^{\prime} \mathrm{E}$ & 160 & 6.48 & 2228 & 8.33 & 100 & 16.60 & 23.89 \\
\hline $\mathrm{Sc} 2$ & $57^{\circ} 33^{\prime} \mathrm{N}$ & $\mathrm{o} 4^{\circ} 17^{\prime} \mathrm{W}$ & 70 & 8.60 & 624 & 17.54 & 91 & 22.77 & 38.36 \\
\hline
\end{tabular}

Lat, latitude; Long, longitude; Alt, altitude (meter above sea level); AMT, annual mean temperature $\left({ }^{\circ} \mathrm{C}\right)$; AMP, annual mean precipitation $(\mathrm{mm})$; $\mathrm{RPD}$, radial penetration depth from bark $(\mathrm{mm})$; age, tree age (year); TH, tree height, $(\mathrm{m})$; Diam., diameter. $\left(\mathrm{cm}_{\mathrm{f}}\right)$. 


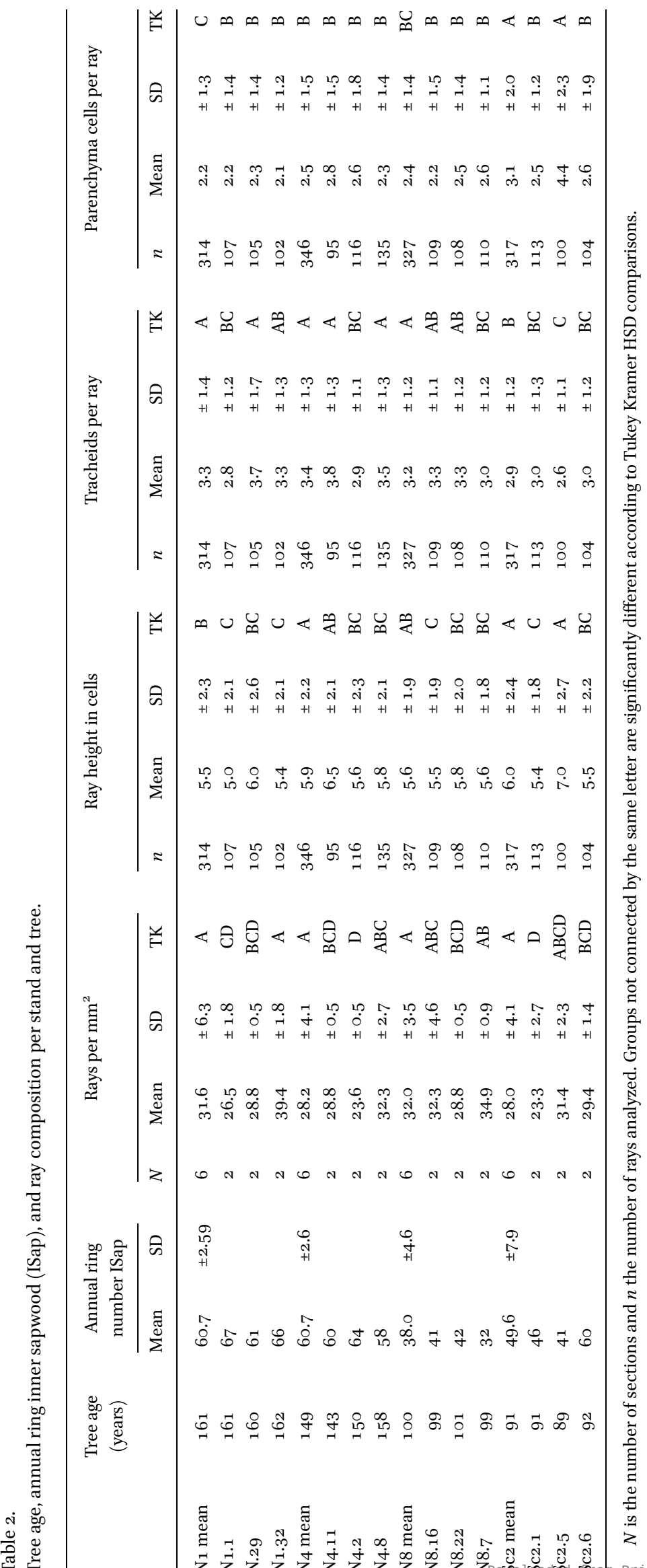



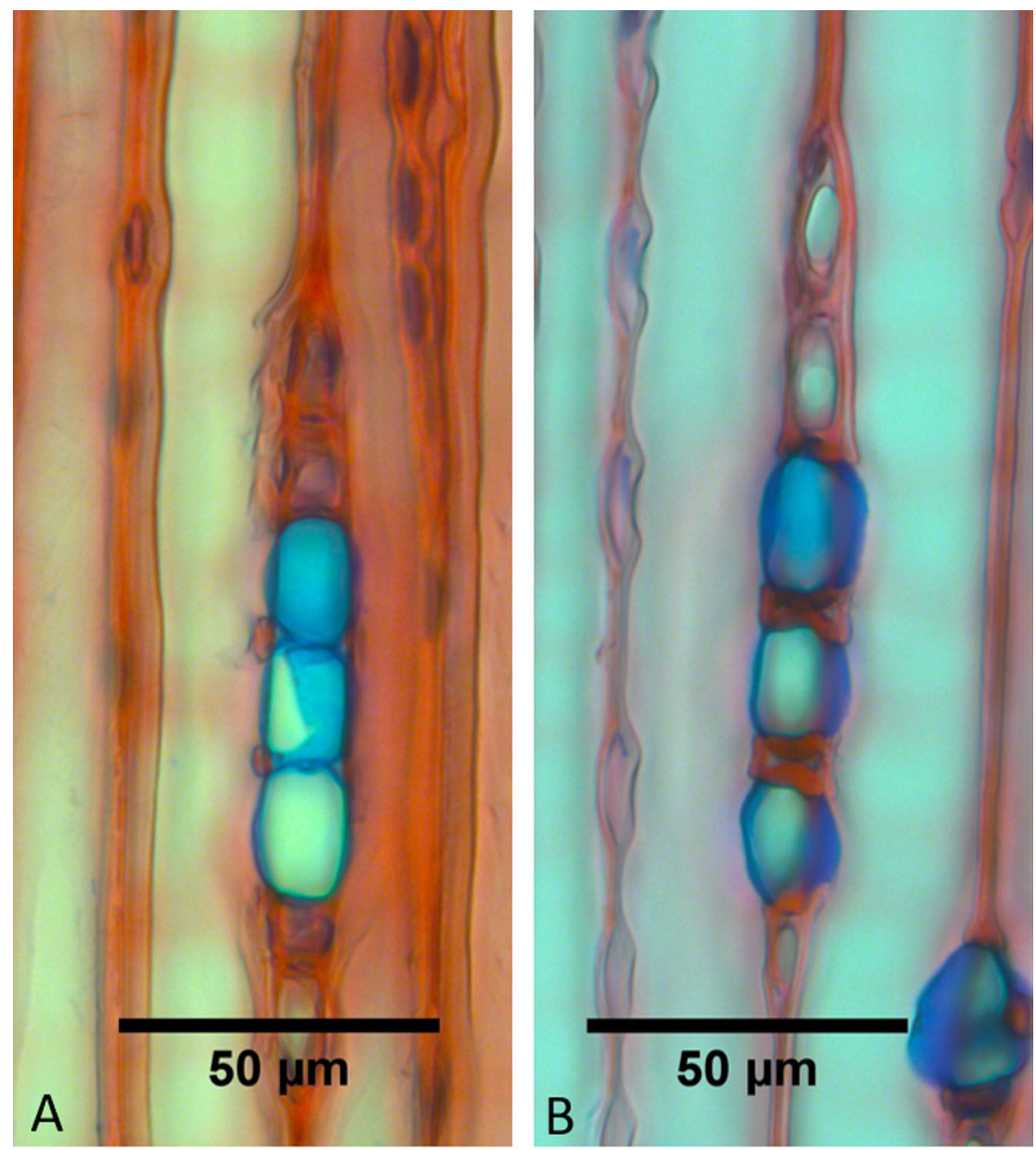

Figure 1. (A) Ray with three parenchyma cells, all unlignified without cell wall thickening. (B) Ray with three parenchyma cells, three with cell wall lignification and thickening.

comparisons of means and t-test, respectively, at a $5 \%$ level of significance. Levels of means are grouped with letters, where groups, which are not connected by the same letter, are significantly different.

\section{RESULTS}

\section{Differences in ray composition and ray frequency}

The prepared samples from the 12 sample trees had an average of $29.82 \pm 5.16$ rays per $\mathrm{mm}^{2}$, ranging from 23.38 (Sc2.1) to 39.22 (N1.32, Table 2). Significant differences were observed between trees, within and between stands.

The most frequent ray height was five to seven cells, and the average ray was composed of two to three ray tracheids and two ray parenchyma cells (Table 2). The composition of the rays in terms of ray height (number of cells) and the number of parenchyma cells per ray (P/R) were similar for the radial positions 'outer sapwood' (OSap) and 'inner sapwood' (ISap) within the trees. Exceptions were tree N4.8, which had a mean ray height of 5.2 cells in the inner sapwood and 6.5 in the outer sapwood (data not shown). In the same tree, the number of parenchyma cells per ray in the inner sapwood (2.6) was significantly higher than the outer sapwood (2.0). However, the median number of parenchyma cells at the two positions was the same (2). Also, tree N8.22 had a significantly different mean number of parenchyma cells per ray after t-test in the outer (2.8) and inner sapwood (2.1). Here, the medians were different for the two radial positions (OSap = 3, ISap = 2). The average number of tracheids per ray in inner and outer sapwood was different for some of the trees (N1.1, N1.32, N4.2, N4.8, Sc2.1, Sc2.5, Sc2.6).

\section{Number and position of lignified and thick-walled parenchyma cells in sapwood}

On a stand average, rays in the outer sapwood (OSap) had a lower relative content of lignified ray parenchyma cells per ray than rays close to the heartwood (inner sapwood, ISap) (Table 3). Averages per stand showe that the Scottish standehad:51:54PM 


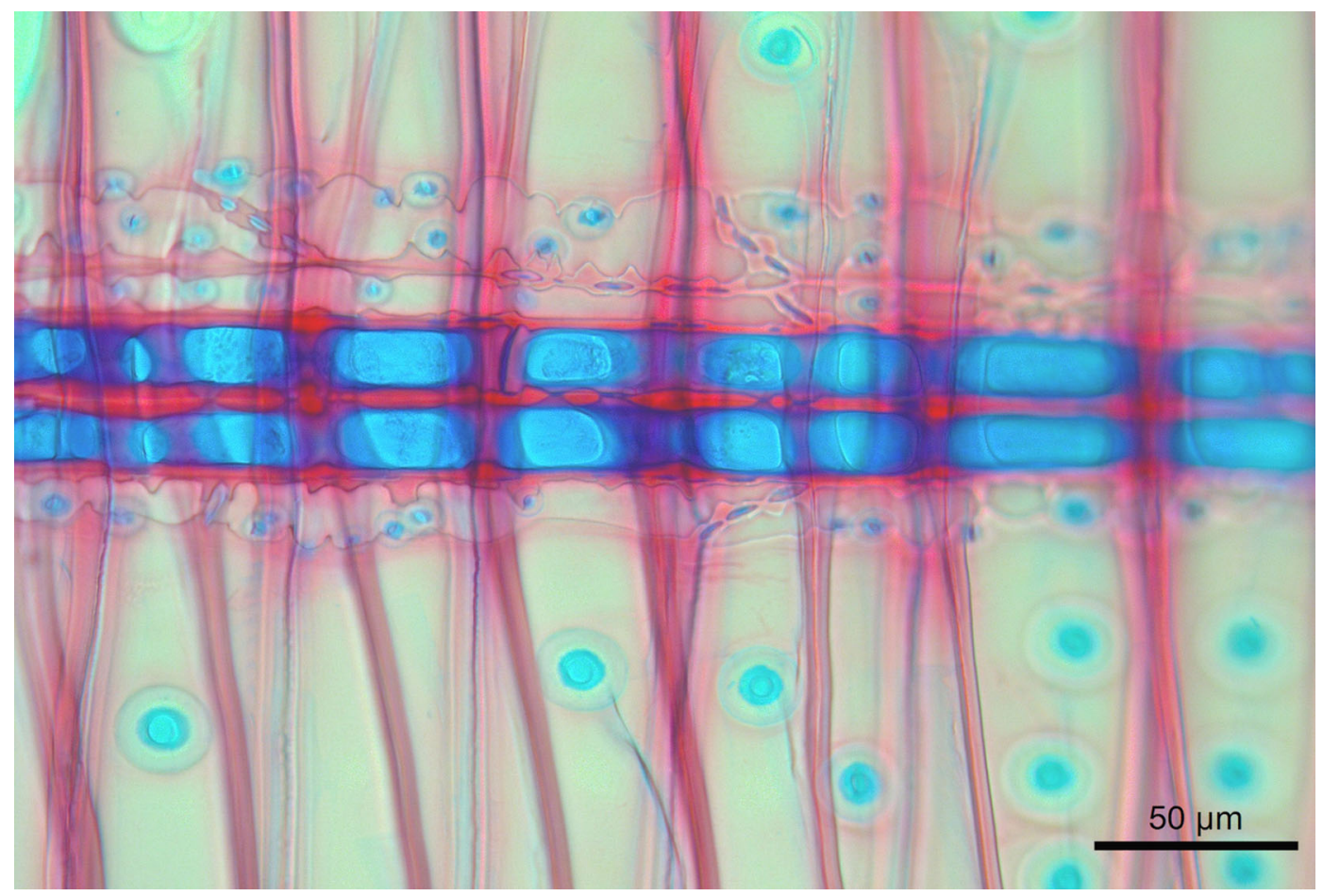

Figure 2. Radial view on a ray, with two ray tracheid rows on the upper margin, two rows of ray parenchyma cells in the center, and one row of ray tracheids on the lower margin of the ray. Lignified (red) and unlignified (blue) areas are distinguishable.

Table 3.

Average relative lignification of parenchyma cells within rays for two radial positions (outer sapwood (OSap) and inner sapwood (ISap)) within a stand.

\begin{tabular}{|c|c|c|c|c|c|c|c|c|}
\hline & \multicolumn{4}{|c|}{ Outer sapwood } & \multicolumn{4}{|c|}{ Inner sapwood } \\
\hline & $N$ & Mean & SD & TK HSD & $N$ & Mean & SD & TK HSD \\
\hline Stand $N_{1}$ & 147 & 24.5 & \pm 34.2 & $\mathrm{C}$ & 143 & 68.0 & \pm 34.0 & B \\
\hline Stand $\mathrm{N}_{4}$ & 161 & 38.4 & \pm 36.0 & B & 161 & 78.3 & \pm 29.4 & A \\
\hline Stand N8 & 169 & $59 \cdot 9$ & \pm 32.2 & A & 146 & 80.5 & \pm 25.8 & A \\
\hline Stand Sc2 & $15^{1}$ & 13.1 & \pm 21.9 & $\mathrm{D}$ & 145 & 63.8 & $\pm 29 \cdot 7$ & B \\
\hline
\end{tabular}

Groups not connected by the same letter are significantly different according to Tukey Kramer HSD comparisons.

the lowest number of lignified RP per ray in OSap (13.1\%. Table 3). In the Norwegian stand N8, lignification was more common in the outer sapwood (present in 59.9\% of ray parenchyma cells). The largest difference in the content of lignified ray parenchyma cells per ray between inner and outer sapwood was found for the Scottish stand (13.1\% OSap - 63.8\% ISap). In $\mathrm{N} 8$, however, the difference was relatively small (20.6\%) since many ray parenchyma cells were already lignified in the outer sapwood.

In all trees, more lignified ray parenchyma cells were found in the inner as compared to the outer sapwood (Figs 3 and 4). In some trees, the difference was as large as $84.7 \%$ (N1.29. Fig. 3) or as small as $4.2 \%$ (N8.22, Fig. 3). When differences were small between inner and outer sapwood, lignification of ray parenchyma cells was common already in the outer sapwood.

In the outer sapwood, Tukey-Kramer HSD comparisons showed significant differences between all stands in the lignification of parenchyma cells within rays for the trees analyzed in this study. In the inner sapwood, these differences were smaller, and only two groups could be identified by Tukey-Kramer HSD comparisons (Table 3). On tree level, relative lignification of parenchyma within rays showed an extensive range within the outer sapwood (74.3\%, N8.22 to 4.3\%, Sc2.1, Fig. 3) and to a minor degree in the inner sapwood (95.4\%, N4.11 to 57.9\%, N1.32, Fig. 3). Tukey-Kramer HSD comparisons showed significant differences in lignification of parenchyma cells in outer sapwood between some of the trees, while most were not significantly different (Fig. 3). In the inner sapwood, significant differences were present between some trees (results not

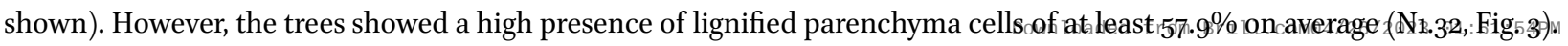




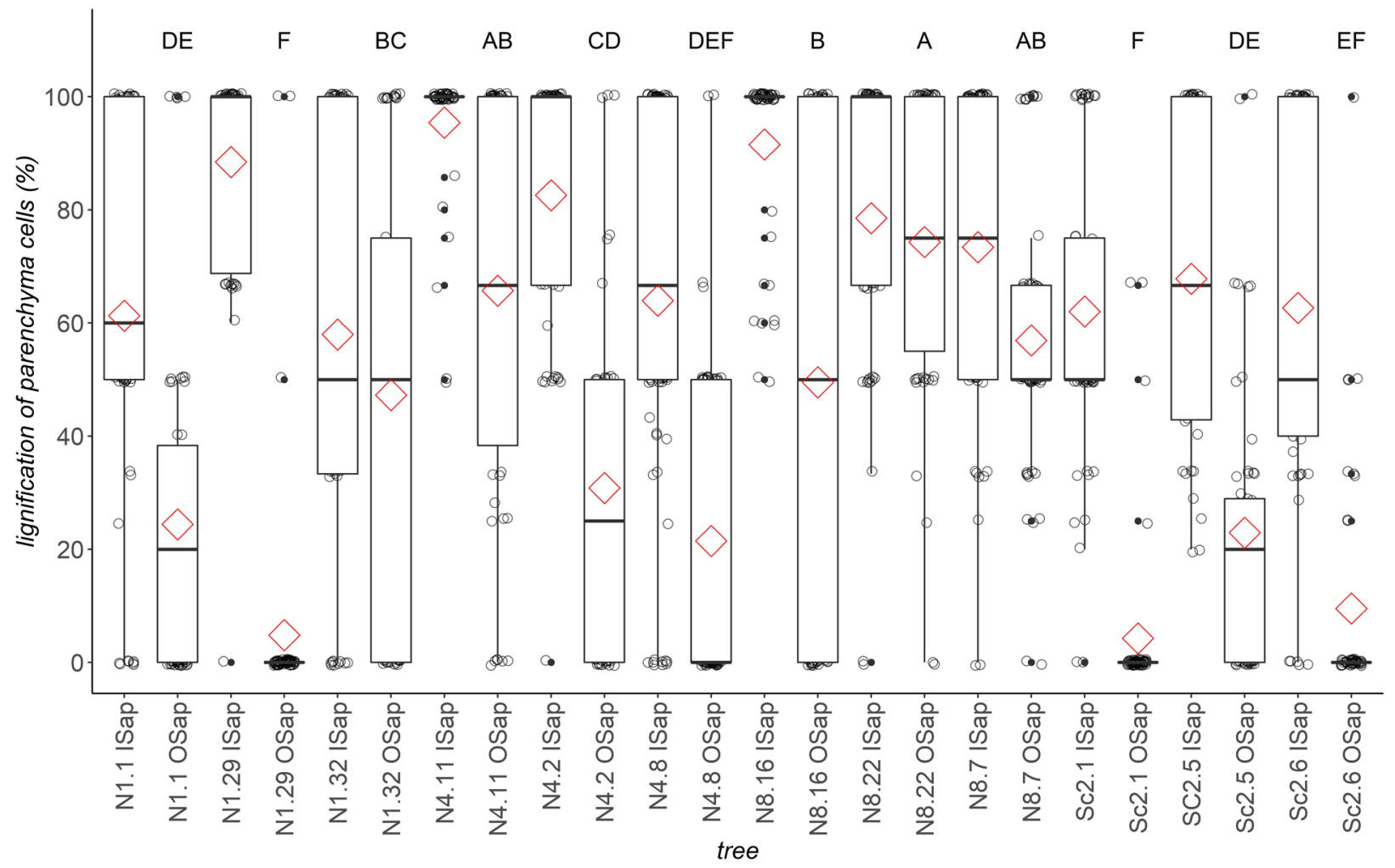

Figure 3. Boxplot of the relative lignification of parenchyma cells within rays for two radial positions (outer sapwood OSap, and inner sapwood ISap). The horizontal middle line in the box plots marks the median, while the red squares mark the mean value of lignification for the radial position of the tree. Levels of means for OSap are grouped with letters, where significantly different groups do not share the same letter.

Fig. 1 (left) shows an example of a ray without lignification of the parenchyma cells. Fig. 1 (right) shows a ray with cell wall lignification in all ray parenchyma cells, while Fig. 2 illustrates ray composition from radial view. Figure 4 indicates how many rays show any sign of lignification (Fig. 4A, outer sapwood, Fig. 4B, inner sapwood). Similar to the results shown in Fig. 3, the differences between trees within the inner sapwood are smaller (Fig. 4B) than within the outer sapwood (Fig. 4A). Between $81 \%$ and $100 \%$ of the rays in the inner sapwood show signs of lignification (Fig. $4 \mathrm{~B}$ ) while this range is much broader in the outer sapwood (6\%, N1.29 to 96\%, N8.22, N8.7, Fig. 4A). In the outer sapwood of the Norwegian stand N8, 67\% (N8.16) and $96 \%$ (N8.22, N8.7) of the rays showed visible signs of lignification. Some of the stands show some trees with a distinctly lower rate. However, none of the stands showed a consistently low amount of lignification in the outer sapwood.

\section{DISCUSSION}

When comparing stands, no difference in the number of rays per $\mathrm{mm}^{2}$ was found (Table 2). Some differences, however, were found between individual trees across and within stands. In earlier studies on structural elements of transverse fluid passage in wood with contrasting treatability, the differences in rays per $\mathrm{mm}^{2}$ were more pronounced (Zimmer et al. 2014a). One of the differences was a higher number of ray parenchyma cells per ray for wood that was easy to treat with impregnation fluids (Zimmer et al. 2014a). These differences were found in wood, which was selected only for their considerable differences in treatability. In the present study, the selection criteria were related to growth conditions and stand location. A ray height of 1-12 cells is reported for Scots pine (Grosser 1977), while Yaman (2007) found an average ray height of 7 ray cells. Significance levels found for ray height in this study are assumed to have only minor relevance since the difference in the mean number of cells is less than one when comparing different stands and less than two when comparing trees.

The rays analyzed in this study were composed on average of two to three ray tracheids, which is slightly lower than literature values, where average values of 3-4 tracheids per ray have been reported (Denne \& Turner 2009). Differences in ray tracheids per ray and ray parenchyma cells per ray are minor within the material studied. The Scottish stand and especially one of the Scottish trees stood out with a higher number of parenchyma cells per ray. This feature, amongst others, was earlier shown to be beneficial for fluid flow during impregnation (Zimmer et al. 2014a). 

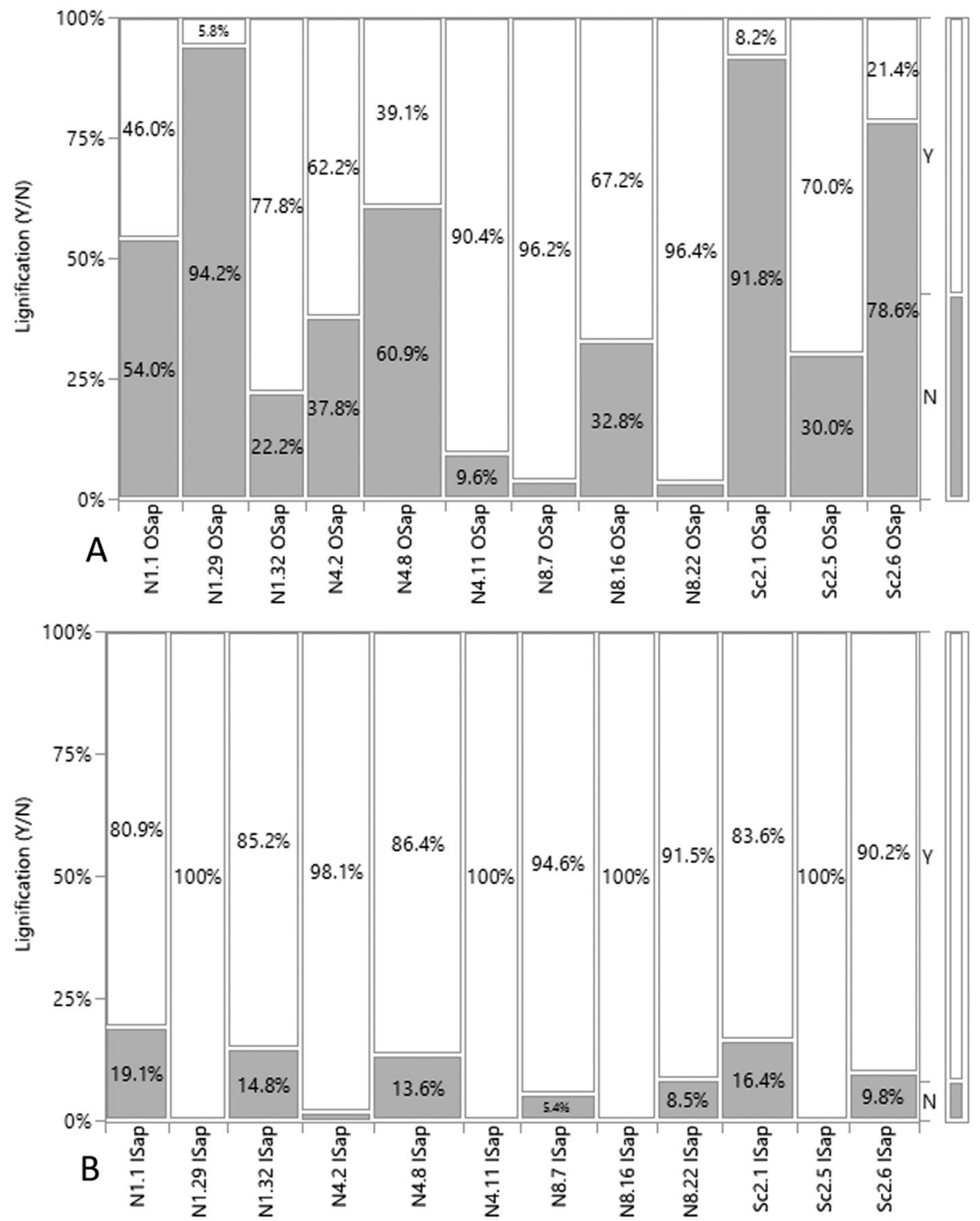

Figure 4. Presence of any sign of lignification in ray parenchyma cells within the ray (yes/no) for the outer $(\mathrm{A})$ and inner $(\mathrm{B})$ sapwood. $($ Yes $=$ white, No = grey).

All trees in our study showed lignification and cell wall thickening of some of the ray parenchyma cells in the inner sapwood before heartwood formation (Figs 3 and 4). Anatomical descriptions of Pinus sylvestris define the ray parenchyma cells in the sapwood as thin-walled, unlignified cells (Grosser 1977). Lignification of parenchyma cells is commonly associated with the transition zone from sapwood to the heartwood (Bergström 2003. Tulik et al. 2019), and not with sapwood areas close to the bark or earlier in the sapwood. The presence of thick and lignified ray parenchyma cell walls in Scots pine sapwood is noted by Bauch et al. (1983), and also Nyrén and Back (1959) described parenchyma cells with thick walls within the non-pit areas alongside thin-walled ones in Northern European pulp fibers. Nyrén and Back (1959) found that $32 \%$ of parenchyma cells were thin-walled in sapwood, while a proportion of $20 \%$ thin-walled parenchyma cells was found in the heartwood. The pulp material also included parenchyma cells from resin canals and could have influenced the proportion of unlignified cells in the study of Nyrén and Back (1959). However, the authors did not study the difference in lignification and cell wall thickening within different radial positions in Scots pine sapwood.

Our results showed a considerable variation in early lignification and cell wall thickening of ray parenchyma cells between stands and between trees. Although the tree age varied between 99 and 162 years, this variation was independent of age but was rather determined by radial position (inner sapwood and outer sapwood) as well as within stand and between stand variations. A more extensive study, including a higher number of trees per stand, is needed tedconfirm thesignificant differences 
in early lignification in the outer sapwood on stand level. The presence of many thick-walled and lignified ray parenchyma cells early in the sapwood can influence the treatability of Scots pine sapwood with impregnation fluids (Zimmer et al. 2014a) since radial flow through the parenchyma cells within the ray would be reduced. Bauch et al. (1983) conducted a treatability test with different Pine species and the refractory softwood species Picea abies [Karst.]. P. abies has a ray structure where all ray parenchyma cells are having thickened and lignified cell walls. In the study of Bauch et al. (1983), it was shown that the species with higher proportions of unlignified and thin-walled ray parenchyma cells, in addition to larger cross-field pits, were easier to impregnate. Different patterns of lignification and cell wall thickening can cause variations in the performance of the material in practice and are particularly relevant for impregnation treatments with protection agents.

The new insights of this study reveal new research opportunities to understand regularities that cause ray parenchyma cells to develop a lignified, thick cell wall before heartwood formation.

\section{CONCLUSIONS}

This study reveals differences in ray anatomy, especially the frequency of thick-walled and lignified ray parenchyma cells in the outer and inner sapwood of Scots pine sapwood. The microscopic analysis of contrast-stained tangential micro-sections shows small differences in the general anatomy of the rays. A considerable variation in the presence of thick-walled and lignified ray parenchyma cells in the outer sapwood is shown in this study, where thickened and lignified cell walls are common in ray parenchyma of some trees. Significant differences for those features are also found between the stands but need confirmation with a higher number of trees per stand. Lignification and cell wall thickening are more common in the inner sapwood, but for some trees, the difference is small due to the already high rate of lignification and cell wall thickening in the outer sapwood. Different patterns of lignification and cell wall thickening can cause variations in the performance of the material in practice and are particularly relevant for impregnation treatments with protection agents. The anatomical differences discovered in this study contribute to a better understanding of the variation in wood properties of Scots pine. The knowledge from this study can be one means of facilitating better purpose-adjusted material selection.

\section{REFERENCES}

Antonova GF, Stasova VV. 1993. Effects of environmental factors on wood formation in Scots pine stems. Trees 7(4): 214-219. DOI: 10.1007/ $\mathrm{BFoO} 2 \mathrm{O} 2076$.

Balatinecz JJ, Kennedy RV. 1967. Maturation of ray parenchyma cells in Pine. For. Prod. J. 17(10): 57-64.

Bamber RK. 1973. The formation and permeability of interstitial spaces in the sapwood of some Pinus species. J. Inst. Wood Sci. 6(2): 36-38.

Bamber RK, Burley J, Bureaux CA. 1983. The wood properties of radiata pine. Commonwealth Agricultural Bureaux.

Bauch J, Liese W, Willeitner H. 1983. Zum Tränkverhalten verschiedener Kiefernarten. Holz als Roh- und Werkstoff 41(8): 339-344. DOI: 10. $1007 / \mathrm{BFO} 2612587$.

Bergström B. 2003. Chemical and structural changes during heartwood formation in Pinus sylvestris. Forestry 76(1): 45-53. DOI: 10.1093/ forestry/76.1.45.

Berninger F. 1997. Effects of drought and phenology on GPP in Pinus sylvestris: a simulation study along a geographical gradient. Funct. Ecol. 11(1): 33-42. DOI: 10.1046/j.1365-2435.1997.00051.X.

Denne P, Turner S. 20o9. Ray structure differences between rootwood and stemwood in a range of softwood species. IAWA J. 30(1): 71-80. DOI: $10.1163 / 22941932-90000204$.

Grosser D. 1977. Die Hölzer Mitteleuropas — Ein mikrophotographischer Lehratlas. Springer. Berlin.

Lande S, Høibø O, Larnøy E. 2010. Variation in treatability of Scots pine (Pinus sylvestris) by the chemical modification agent furfuryl alcohol dissolved in water. Wood Sci. Technol. 44(1): 105-118. DOI: 10.1007/soo226-0o9-0272-3.

Mann PT. 1974. Ray parenchyma cell-wall ultrastructure and formation in Pinus banksiana. Wood Fibre Sci. 6(1): 18-25.

Martin JA, Esteban LG, de Palacios P, Fernandez FG. 2010. Variation in wood anatomical traits of Pinus sylvestris L. between Spanish regions of provenance. Trees 24(6): 1017-1028. DOI: 10.1007/soo468-010-0471-4.

Martínez-Vilalta J, Cochard H, Mencuccini M, Sterck F, Herrero A, Korhonen JFJ, Llorens P, Nikinmaa E, Nolè A, Poyatos R, Ripullone F, Sass-Klaassen U, Zweifel R. 20o9. Hydraulic adjustment of Scots pine across Europe. New Phytol. 184(2): 353-364. DOI: 10.1111/j.14698137.2009.02954.x.

Mátyás C, Ackzell L, Samuel CJA. 2004. EUFORGEN technical guidelines for genetic conservation and use for Scots pine (Pinus sylvestris). International Plant Genetic Resources Institute. Rome, Italy.

McCann MC. 1997. Tracheary element formation: building up to a dead end. Trends Plant Sci. 2(9): 333-338. DOI: 10.1016/S136o-1385(97) 84620-1.

Nakaba S, Kubo T, Funada R. 20o8. Differences in patterns of cell death between ray parenchyma cells and ray tracheids in the conifers Pinus densiflora and Pinus rigida. Trees 22(5): 623-630. DOI: 10.1007/soo468-0o8-0220-o.

Nyrén V, Back E. 1959. Characteristics of parenchymatous cells and tracheidal ray cells of Pinus sylvestris pulpwood. The resin in parenchymatous cells and resin canals of conifers. III. Norsk Skogindustri 13(8): 267-278. 
Poyatos R, Martínez-Vilalta J, Čermák J, Ceulemans R, Granier A, Irvine J, Köstner B, Lagergren F, Meiresonne L, Nadezhdina N, Zimmermann R, Llorens P, Mencuccini M. 2007. Plasticity in hydraulic architecture of Scots pine across Eurasia. Oecologia 153(2): $245^{-259 .}$ DOI: $10.1007 /$ soo442-007-0740-0.

Spicer R, Holbrook NM. 2007. Parenchyma cell respiration and survival in secondary xylem: does metabolic activity decline with cell age? Plant Cell Environ. 30(8): 934-943. DOI: 10.1111/j.1365-3040.2007.01677.x.

Srebotnik E, Messner K. 1994. A simple method that uses differential staining and light microscopy to assess the selectivity of wood delignification by white rot fungi. App. Environ. Biol. 6o(4): 1383-1386. DOI: 10.1128/AEM.6o.4.1383-1386.1994.

Tulik M, Jura-Morawiec J, Bieniasz A, Marciszewska K. 2019. How long do wood parenchyma cells live in the stem of a Scots pine (Pinus sylvestris L.)? Studies on cell nuclei status along the radial and longitudinal stem axes. Forests 10: 977. DOI: 10.339o/fio110977.

Wagenführ R. 2007. Holzatlas. Fachbuchverlag Leipzig.

Yaman B. 2007. Comparative wood anatomy of Pinus sylvestris and its var. compacta in the west Black Sea region of Turkey. IAWA J. 28(1): 75-81. DOI: 10.1163/22941932-90oo1620.

Zheng PM, Aoki D, Yoshida M, Matsushita Y, Imai T, Fukushima K. 2014. Lignification of ray parenchyma cells in the xylem of Pinus densiflora. Part I: Microscopic investigation by POM, UV microscopy, and TOF-SIMS. Holzforschung 68(8): 897-905. DOI: 10.1515/hf-2013-0231.

Zimmer K, Treu A, McCulloh KA. 2014a. Anatomical differences in the structural elements of fluid passage of Scots pine sapwood with contrasting treatability. Wood Sci. Technol. 48(2): 435-447. DOI: 10.1007/soo226-014-0619-2.

Zimmer KP, Høibø OA, Vestøl GI, Larnøy E. 2014b. Variation in treatability of Scots pine sapwood: a survey of 25 different northern European locations. Wood Sci. Technol. 48(5): 1049-1068. DOI: 10.1007/soo226-014-o66o-1.

Edited by Lloyd Donaldson 